\title{
VAŽNOST SLIKE TIJELA KAO MODERATOR ODNOSA IZMEĐU ZADOVOLJSTVA SLIKOM TIJELA I KORIŠTENJA STRATEGIJA ZA SMANJENJE TEŽINE
}

\author{
Miljana Kukić \\ Filozofski fakultet u Rijeci, Odsjek za psihologiju \\ Sveučilišna avenija 4, 51000 Rijeka \\ mkukic@ffri.hr
}

\begin{abstract}
Sažetak
Cilj ovoga istraživanja bio je ispitati spolne razlike u slici tijela i uporabi strategija za smanjenje težine te ispitati mogući moderatorski učinak važnosti slike tijela na odnos između nezadovoljstva slikom tijela i korištenja strategija za smanjenje težine $\mathrm{u}$ adolescenata.

U istraživanju je sudjelovalo ukupno 913 srednjoškolaca (65,7\% djevojaka, prosječna dob 16,2 $\pm 1,18$ godina). Primijenjen je Inventar slike tijela i strategija za promjenu tjelesnog izgleda.

Rezultati su pokazali da su djevojke, općenito, nezadovoljnije svojom slikom tijela, pridaju joj veću važnost te češće koriste strategije za smanjenje težine nego mladići. Rezultati regresijskih analiza pokazali su da važnost slike tijela ima moderatorski učinak na odnos između nezadovoljstva slikom tijela i korištenja strategija za smanjenje težine. Mladići i djevojke koji su nezadovoljni svojom tjelesnom težinom, a ujedno joj pridaju visoku važnost, češće koriste strategije za smanjenje težine nego mladići i djevojke koji su nezadovoljni tjelesnom težinom, ali joj ne pridaju visoku važnost. Isti je obrazac prisutan u međuodnosu važnosti izgleda pojedinih dijelova tijela, nezadovoljstva izgledom pojedinih dijelova tijela i korištenja strategija za smanjenje težine.

Ovo istraživanje pruža dodatni uvid u ulogu važnosti slike tijela u adolescenata. Rezultati ovoga istraživanja mogu se koristiti kao smjernice za osmišljavanje preventivnih programa usmjerenih na nezadovoljstvo slikom tijela i njegove posljedice.
\end{abstract}

Ključne riječi: nezadovoljstvo slikom tijela, važnost slike tijela, strategije za smanjenje težine, adolescencija

\section{UVOD}

Slika tijela višedimenzionalni je konstrukt, a predstavlja mentalnu sliku osobe o vlastitom izgledu, mišljenja i osjećaje vezane uz izgled, kao i ponašanja koja iz 
toga proizlaze (Rosen, 1992; Thompson, Heinberg, Altabe i Tantleff-Dunn, 1999). Pažnju istraživača najviše zaokuplja njezina afektivna komponenta, odnosno nezadovoljstvo tijelom, čiju srž čini diskrepanca između percepcije vlastitoga izgleda i željenoga, idealnog izgleda (Gardner, Friedman i Jackson, 1999). Kako je društveno definiran ideal tjelesnoga izgleda većini nedostižan (visoko, vitko, čvrsto, ali ne pretjerano mišićavo, mršavo tijelo bujnoga poprsja u žena; mišićavo tijelo širokih ramena, ravnoga trbuha i uskoga struka i bokova u muškaraca), internalizacija takvoga ideala i težnja $\mathrm{k}$ njemu često i lako dovodi do nezadovoljstva (Levine i Smolak, 2002; Tiggemann, 2011; Thompson i Stice, 2001). To posebno dolazi do izražaja u adolescenciji, kada tjelesni izgled dobiva na važnosti i postaje jedna od ključnih odrednica samovrednovanja, te svako odstupanje od idealne tjelesne figure može rezultirati nezadovoljstvom tijelom.

Rezultati istraživanja pokazuju da čak do $60 \%$ djevojaka i $30 \%$ mladića izražava želju za promjenom težine ili oblika tijela (Ricciardelli i McCabe, 2001). Prema istraživanju koje su na uzorku od 1035 učenika prvih i četvrtih razreda srednjih škola s područja Hrvatske napravile Pokrajac-Bulian, Mohorić i Đurović (2007), 35,6\% djevojaka nezadovoljno je ili jako nezadovoljno težinom, a njih 19,4\% izgledom, dok je u mladića težinom nezadovoljno ili jako nezadovoljno njih $13 \%$, a izgledom $6,8 \%$. Iako većina istraživanja upućuje na veće zadovoljstvo izgledom u mladića, neka istraživanja ne pronalaze spolne razlike (primjerice, McCabe, Ricciardelli i Holt, 2010).

Nezadovoljstvo tijelom ima značajne implikacije za funkcioniranje adolescenata. Istraživanja provedena na uzorcima hrvatskih adolescenata potvrđuju povezanost nezadovoljstva slikom tijela i samopoštovanja, ali i drugih pokazatelja psihičkog zdravlja, poput somatskog stresa, anksioznosti, depresivnosti i zadovoljstva životom (Sujoldžić i De Lucia, 2007). Osim toga, nezadovoljstvo tijelom jedan je od ključnih čimbenika povezanih s korištenjem strategija za promjenu tjelesnog izgleda (McCabe i sur., 2010; Muris, Meesters, van de Blom i Mayer, 2005), što potvrđuju i istraživanja rađena na hrvatskim uzorcima (Ambrosi-Randić, 2001; Bralić i Kovačić, 2005; Knez, 2003; Peternel i Sujoldžić, 2009; Škreblin, 2003).

Nezdrave strategije za smanjenje težine, poput restriktivnog hranjenja, preskakanja obroka, uzimanja tableta za mršavljenje, povraćanja, pretjerane tjelovježbe i slično, mogu biti povezane s razvojem poremećaja hranjenja i drugih ozbiljnih posljedica na području mentalnog i tjelesnog zdravlja, kao, primjerice, depresivnosti, anksioznosti, ali i metaboličkih, nutritivnih i endokrinoloških problema (Crow, Eisenberg, Story i Neumark-Sztainer, 2006; French i Jeffery, 1994; Goldschmidt, Aspen, Sinton, Tanofsky-Kraff i Wilfley, 2008; Gutin, 2011). Korištenje nezdravih strategija osobito je opasno u adolescenciji, kada je razvoj još uvijek u tijeku (Calderon, Yu i Jambazian, 2004). Upravo zbog toga, zabrinjavajući su podaci o raširenosti provođenja dijete, kao najčešće korištene metode za kontrolu težine, među mladima. Ranije spomenuto istraživanje autorica Pokrajac-Bulian i sur. (2007) pokazalo 
je da dijetu provodi oko 40\% djevojaka i 14\% mladića, a kao razlog najčešće navode želju za poboljšanjem izgleda.

Sama prisutnost nezadovoljstva tijelom neće u svih dovesti do korištenja postupaka kojima se pokušava utjecati na oblik ili težinu tijela (Goldschmidt i sur., 2008), već bitnu ulogu igra i važnost koju osoba pridaje slici tijela (McCabe i Ricciardelli, 2003; McCabe i sur., 2010). Zadovoljstvo slikom tijela, kao aspekt slike tijela, zastupljeno je u velikom broju istraživanja iz područja poremećaja hranjenja i pretilosti. Međutim, važnost koju osoba pridaje slici tijela komponenta je slike tijela koju istraživači često zapostavljaju, usprkos njenoj teorijskoj i kliničkoj značajnosti za razumijevanje razvoja poremećaja hranjenja (Cooper i Fairburn, 1993) i općenito utjecaju na funkcioniranje osobe (Rieder i Ruderman, 2001).

Ricciardelli i McCabe (2001) navode kako sam podatak da netko želi vitkije ili krupnije tijelo ne govori mnogo. Smatraju da je ključno znati koliko je osobi važno imati vitkije ili krupnije tijelo, jer će upravo to odrediti razinu njezina nezadovoljstva tijelom i utjecaj nezadovoljstva na druge aspekte života. Ovakvo je razmišljanje u skladu s kognitivnim modelom koji ističe da vjerovanja osobe, što bi u kontekstu ovoga rada bila vjerovanja o važnosti tjelesnoga izgleda, utječu na način na koji ta osoba vidi određenu situaciju, što zatim utječe na njene misli, osjećaje i ponašanja (Beck, 2011). Ako osobi tjelesni izgled nije posebno važan, mala je vjerojatnost da će utjecati na njezin osjećaj vlastite vrijednosti, čak i kada je nezadovoljna njime (Ricciardelli i McCabe, 2001). Osoba nezadovoljna vlastitom težinom, ali kojoj je slika tijela tek marginalno važna, bit će manje motivirana koristiti razne metode za kontrolu težine nego osoba jednako nezadovoljna težinom, ali koja težinu vidi kao nešto presudno za osjećaj vlastite vrijednosti (Rieder i Ruderman, 2001). McCabe i Ricciardelli (2003) smatraju da će se samo one osobe koje pridaju visoku važnost slici tijela upuštati u ponašanja kojima je cilj promijeniti tjelesni izgled. Istraživanja to uglavnom potvrđuju te ističu da se utjecaj važnosti slike tijela na korištenje strategija za promjenu tjelesnog izgleda ponešto razlikuje ovisno o spolu osoba (McCabe i sur., 2010; Muris i sur., 2005; Ricciardelli i McCabe, 2003).

Istraživanja koja su uspoređivala mladiće i djevojke adolescentne dobi s obzirom na važnost slike tijela ne daju ujednačene rezultate. Jedna pokazuju da djevojke pridaju veću važnost slici tijela (McCabe i Ricciardelli, 2001), druga da su mladići ti kojima je ona važnija (McCabe i sur., 2010), dok treća ne pronalaze spolne razlike (McCabe i Ricciardelli, 2005). Neka istraživanja rađena na uzorcima preadolescenata razmatrala su zasebno važnost koju osobe pridaju tjelesnoj težini i važnost koju pridaju mišićavosti. Pokazalo se da dječaci u značajno većoj mjeri nego djevojčice pridaju važnost mišićavosti (McCabe, Ricciardelli i Holt, 2005; Ricciardelli, McCabe, Holt i Finemore, 2003). No, pri ispitivanju važnosti koju sudionici pridaju tjelesnoj težini, rezultati nisu jednoznačni. Neka istraživanja navode da djevojčice pridaju veću važnost tjelesnoj težini (McCabe i sur., 2005), a druga da podjednaki broj djevojčica i dječaka smatra tjelesnu težinu važnom (Ricciardelli i sur., 2003). 
S obzirom na nejednoznačnost rezultata istraživanja koja su se bavila ispitivanjem spolnih razlika u nezadovoljstvu slikom tijela i važnosti slike tijela u adolescenata, cilj ovoga istraživanja bio je ispitati razlikuju li se mladići i djevojke srednjoškolske dobi u zadovoljstvu slikom tijela, važnosti koju pridaju tjelesnom izgledu te korištenju strategija za smanjenje težine, kao jednom od njihovih korelata. Cilj istraživanja bio je i ispitati odnos među navedenim varijablama. Polazeći od kognitivnog modela, a s obzirom na nedostatne rezultate istraživanja, željeli smo provjeriti ima li važnost slike tijela moderatorski učinak na odnos između zadovoljstva slikom tijela i korištenja strategija za smanjenje težine.

\section{METODA}

\section{Sudionici}

U istraživanju je sudjelovalo ukupno 913 učenika i učenica od prvog do četvrtog razreda srednjih škola s područja gradova Rijeke i Opatije. Ispitani uzorak činilo je 600 djevojaka (65,7\%) i 313 mladića $(34,3 \%)$, u dobi od 14 do 19 godina $(\mathrm{M}=$ $16,22, \mathrm{SD}=1,18)$.

Na temelju podataka o tjelesnoj težini i visini sudionika, izračunat je indeks tjelesne mase sudionika [ITM = tjelesna težina pojedinca (u kilogramima) / kvadrat tjelesne visine (u metrima)]. Pomoću tablica s centilnim vrijednostima ITM-a hrvatskih dječaka i djevojčica u dobi od 6,5 do 18,5 godina (Jureša, Musil i Kujundžić Tiljak, 2010), određena je uhranjenost sudionika. Rezultati pokazuju da je $2,9 \%$ sudionika pothranjeno (ITM ispod 5. centila za dob i spol), $84,7 \%$ normalne je tjelesne težine (ITM od 5. do 84. centila za dob i spol), 8,7\% sudionika je prekomjerno teško (ITM od 85. do 94. centila za dob i spol), a 3,7\% pretilo (ITM jednak ili veći od 95. centila za dob i spol). Za šestero sudionika (tri djevojke i tri mladića) nije bilo moguće odrediti stupanj uhranjenosti jer nisu pružili podatke o svojoj težini i/ili visini. U Tablici 1 prikazana je uhranjenost sudionika s obzirom na spol.

Tablica 1. Broj sudionika s obzirom na uhranjenost i spol

\begin{tabular}{lccc}
\hline Klasifikacija uhranjenosti & Mladići & Djevojke & Ukupno \\
\hline Pothranjenost & 6 & 20 & $26(2,9 \%)$ \\
Normalna težina & 267 & 501 & $768(84,7 \%)$ \\
Prekomjerna težina & 24 & 55 & $79(8,7 \%)$ \\
Pretilost & 13 & 21 & $34(3,7 \%)$ \\
\hline Ukupno & 310 & 597 & $907(100,0 \%)$ \\
\hline
\end{tabular}




\section{Instrumentarij}

U ovom su istraživanju primijenjene tri ljestvice Inventara slike tijela i strategija za promjenu tjelesnog izgleda (Body Image and Body Change Inventory; Ricciardelli i McCabe, 2000): ljestvica Zadovoljstva slikom tijela, Važnosti slike tijela i Strategija za smanjenje težine. Navedene su ljestvice prevedene na hrvatski jezik metodom dvostrukoga prijevoda i prilagođene populaciji hrvatskih učenika (Kukić, 2013). Osim rječnika, prilagođen je i oblik odgovaranja. Naime, originalni način odgovaranja koji su koristile Ricciardelli i McCabe (2000), od "jako zadovoljan", "jako važno" i "uvijek" krajnje lijevo na ljestvici do "jako nezadovoljan", "jako nevažno" i "nikada" krajnje desno, prilagođen je uobičajenom načinu procjenjivanja u hrvatskim istraživanjima tako što su polovima na ljestvici za odgovore zamijenjena mjesta (polovi "jako zadovoljan", "jako važno" i "uvijek" stavljeni su krajnje desno, a polovi "jako nezadovoljan", "jako nevažno" i "nikada" krajnje lijevo).

Ljestvica Zadovoljstva slikom tijela (Body Image Concern) korištena je za procjenu nezadovoljstva tjelesnim izgledom, a ljestvica Važnosti slike tijela (Body Image Importance) za procjenu važnosti koju osoba pridaje vlastitom izgledu. Obje se ljestvice sastoje od 10 čestica. Prve 3 čestice svake ljestvice su samostalne i mjere zadovoljstvo pojedinim aspektima tjelesnog izgleda (tjelesnom težinom, oblikom tijela te mišićnom masom), odnosno mjere važnost koju osoba pridaje svakom od tih aspekata. Preostalih 7 čestica mjeri koliko je osoba zadovoljna izgledom pojedinih dijelova svojega tijela (bokovima, bedrima, prsima, trbuhom, ramenima, nogama i rukama), odnosno koliko je osobi važan izgled tih dijelova tijela. U obje ljestvice, sudionici odgovaraju na čestice na skali Likertova tipa od 5 stupnjeva (od 1 - jako nezadovoljan/jako nevažno do 5 - jako zadovoljan/jako važno). Primjenom ljestvica mogu se dobiti pojedinačni rezultati o zadovoljstvu tjelesnom težinom, oblikom tijela te mišićnom masom, odnosno pojedinačni rezultati o važnosti tih aspekata izgleda. Također, mogu se dobiti i rezultati koji označavaju ukupnu mjeru zadovoljstva izgledom pojedinih dijelova tijela, odnosno ukupnu mjeru važnosti izgleda pojedinih dijelova tijela. Ovi se rezultati oblikuju kao jednostavne linearne kombinacije procjena na 7 čestica koje ispituju zadovoljstvo izgledom pojedinih dijelova tijela, odnosno 7 čestica koje ispituju važnost izgleda pojedinih dijelova tijela. Viši rezultat upućuje na veće zadovoljstvo izgledom pojedinih dijelova tijela, odnosno na veću važnost koju osoba pridaje izgledu pojedinih dijelova tijela. Na našem uzorku, koeficijent pouzdanosti tipa Cronbach alpha ljestvice Zadovoljstva slikom tijela iznosi 0,85 , odnosno 0,88 za ljestvicu Važnosti slike tijela.

Ljestvica Strategija za smanjenje težine (Body Change Strategies to Lose Weight) sastoji se od 9 čestica. Ispituje učestalost korištenja pojedinih strategija za smanjivanje tjelesne težine (promjene navika hranjenja, pojačana tjelovježba te korištenje pripravaka za mršavljenje). Sudionici na svaku česticu odgovaraju na skali Likertova tipa od 5 stupnjeva s obzirom na to koliko često koriste pojedinu strategiju (od 1 - nikad do 5 - uvijek). Jednostavnom linearnom kombinacijom procjena 
na svim česticama ove ljestvice dobiva se ukupan rezultat. Viši rezultat upućuje na češće korištenje različitih strategija za smanjenje tjelesne težine. Na našem uzorku, koeficijent pouzdanosti tipa Cronbach alpha ove ljestvice iznosi 0,94.

Upitnikom su prikupljeni i podaci o spolu, dobi, razredu, kao i trenutačnoj tjelesnoj visini i težini učenika.

\section{Postupak}

Prije početka provedbe istraživanja, od nadležnih su tijela i institucija (Etičkog povjerenstva za istraživanja s ljudima Odsjeka za psihologiju Filozofskog fakulteta u Zagrebu, Ministarstva znanosti, obrazovanja i sporta Republike Hrvatske te ravnateljstava srednjih škola u kojima se provodilo istraživanje) dobivena odobrenja za provođenje ispitivanja. Svoje su pristanke dali i sami sudionici istraživanja.

Ispitivanje je provođeno grupno u dogovorenim terminima unutar redovnog školskog rasporeda. Po dolasku u razred, ispitivači su učenicima objasnili svrhu istraživanja te im podijelili detaljne formulare za informirane pristanke na sudjelovanje $u$ istraživanju. Nakon potpisivanja pristanka, učenicima su podijeljeni upitnici. Sudjelovanje u ispitivanju bilo je dobrovoljno i anonimno, a zadatak sudionika bio je ispunjavanje upitnika tipa papir-olovka.

\section{Statističke analize}

Statističke analize podataka napravljene su pomoću računalnog programa SPSS, verzija 15.0 (SPSS Inc., 2006). Za ispitivanje razlika u zadovoljstvu slikom tijela, važnosti tjelesnog izgleda i strategija za smanjenje težine s obzirom spol sudionika korišteni su t-testovi za nezavisne uzorke. Provedene su i korelacijske analize između svih ispitanih varijabli (Pearsonov koeficijent korelacije). S ciljem ispitivanja potencijalnog moderatorskog učinka važnosti tjelesnog izgleda na odnos između zadovoljstva slikom tijela i strategija za smanjenje težine, provedene su hijerarhijske regresijske analize s interakcijskim učincima.

Iz svih su obrada podataka isključeni učenici i učenice koji nisu dali podatke o tjelesnoj težini i visini $(n=6)$. Isključeni su oni koji se prema tablicama s centilnim vrijednostima ITM-a za dob i spol ubrajaju u kategoriju pothranjenih $(\mathrm{n}=26)$, s obzirom na očekivane spolne razlike u strategijama za promjenu tjelesnog izgleda u ovoj kategoriji sudionika.

\section{REZULTATI}

U Tablici 2 prikazani su deskriptivni podaci za korištene ljestvice Inventara slike tijela i strategija za promjenu tjelesnog izgleda dobiveni u ovom istraživanju. 
Tablica 2. Deskriptivna statistika za korištene ljestvice $(\mathrm{N}=881)$

\begin{tabular}{lcccc}
\hline Ljestvica & $\begin{array}{c}\text { Broj } \\
\text { čestica }\end{array}$ & $M$ & $S D$ & $\begin{array}{c}\text { Raspon } \\
\text { rezultata }\end{array}$ \\
\hline Zadovoljstvo tjelesnom težinom & 1 & 3,56 & 1,11 & $1,00-5,00$ \\
Zadovoljstvo oblikom tijela & 1 & 3,59 & 0,94 & $1,00-5,00$ \\
Zadovoljstvo mišićnom masom & 1 & 3,43 & 0,93 & $1,00-5,00$ \\
Zadovoljstvo izgledom pojedinih dijelova tijela & 7 & 3,51 & 0,77 & $1,00-5,00$ \\
Važnost tjelesne težine & 1 & 3,21 & 1,11 & $1,00-5,00$ \\
Važnost oblika tijela & 1 & 3,41 & 1,04 & $1,00-5,00$ \\
Važnost veličine i snage mišića & 1 & 2,78 & 1,13 & $1,00-5,00$ \\
Važnost izgleda pojedinih dijelova tijela & 7 & 3,20 & 0,94 & $1,00-5,00$ \\
Strategije za smanjenje težine & 9 & 2,05 & 1,01 & $1,00-5,00$ \\
\hline
\end{tabular}

Legenda: $M=$ aritmetička sredina; $S D=$ standardna devijacija

U tablici su navedeni podaci o aritmetičkim sredinama, standardnim devijacijama i rasponu rezultata iskazani u relativnim vrijednostima.

Iz Tablice 2 vidimo da su sudionici u prosjeku umjereno zadovoljni svojom tjelesnom težinom, oblikom tijela i izgledom pojedinih dijelova tijela, dok svojom mišićnom masom nisu niti zadovoljni niti nezadovoljni. Rezultati su također pokazali da u prosjeku sudionicima različiti aspekti tjelesnog izgleda (tjelesna težina, oblik tijela, veličina i snaga mišića te izgled pojedinih dijelova tijela) nisu niti važni niti nevažni. U prosjeku, sudionici tek ponekad koriste strategije za smanjenje težine, iako ima i onih koji ih koriste uvijek.

Provedeni su t-testovi za nezavisne uzorke u cilju ispitivanja razlika između mladića i djevojaka u zadovoljstvu slikom tijela, važnosti koju pridaju tjelesnom izgledu te učestalosti korištenja strategija za smanjenje težine. Rezultati provedenih analiza prikazani su u Tablici 3.

Rezultati t-testova prikazani u Tablici 3 upućuju na postojanje statistički značajnih spolnih razlika u svim mjerenim varijablama, s izuzetkom zadovoljstva mišićnom masom. Mladići, u usporedbi s djevojkama, zadovoljniji su svojom tjelesnom težinom, oblikom tijela, te izgledom pojedinih dijelova svojega tijela. S druge strane, djevojkama je važnije nego mladićima kako im izgledaju pojedini dijelovi tijela, a veću važnost pridaju i svojoj tjelesnoj težini te obliku tijela. Mladići veću važnost pridaju samo veličini i snazi mišića. Sukladno očekivanjima, djevojke statistički značajno češće nego mladići koriste strategije za smanjenje težine.

Povezanost između ispitanih varijabli provjerena je korelacijskim analizama (Pearsonovi koeficijenti korelacije). Ove su analize provedene zasebno na poduzorcima mladića i djevojaka s obzirom na to da se teorijski očekuju spolne razlike u 
Tablica 3. Analiza razlika u zadovoljstvu slikom tijela, važnosti slike tijela te strategijama za smanjenje težine između mladića $(\mathrm{n}=304)$ i djevojaka $(\mathrm{n}=577)$

\begin{tabular}{lcccccc}
\hline & \multicolumn{3}{c}{ Mladići } & \multicolumn{2}{c}{ Djevojke } & \multirow{2}{*}{$t$} \\
\cline { 2 - 5 } & $M$ & $S D$ & $M$ & $S D$ & \\
\hline Zadovoljstvo tjelesnom težinom & 3,74 & 1,04 & 3,47 & 1,13 & $3,38^{* *}$ \\
Zadovoljstvo oblikom tijela & 3,68 & 0,89 & 3,55 & 0,96 & $2,01^{*}$ \\
Zadovoljstvo mišićnom masom & 3,50 & 0,95 & 3,40 & 0,91 & 1,53 \\
Zadovoljstvo izgledom pojedinih dijelova tijela & 3,59 & 0,80 & 3,47 & 0,76 & $2,20^{*}$ \\
Važnost tjelesne težine & 2,78 & 1,15 & 3,43 & 1,03 & $8,63^{* * *}$ \\
Važnost oblika tijela & 3,09 & 1,10 & 3,58 & 0,96 & $6,86^{* * *}$ \\
Važnost veličine i snage mišića & 3,16 & 1,08 & 2,58 & 1,11 & $7,51^{* * *}$ \\
Važnost izgleda pojedinih dijelova tijela & 2,93 & 1,02 & 3,35 & 0,86 & $6,47^{* * *}$ \\
Strategije za smanjenje težine & 1,53 & 0,76 & 2,32 & 1,02 & $11,86^{* * *}$ \\
\hline
\end{tabular}

$* \mathrm{p}<0,05 ; * * \mathrm{p}<0,01 ; * * \mathrm{p}<0,001$

međuodnosu ispitivanih varijabli, a ujedno su ovim istraživanjem utvrđene statistički značajne spolne razlike u zadovoljstvu slikom tijela, važnosti slike tijela, kao i korištenju strategija za smanjenje težine. Rezultati korelacijskih analiza prikazani su u Tablici 4.

Iz Tablice 4 vidimo da je indeks tjelesne mase negativno povezan s gotovo svim mjerenim aspektima zadovoljstva slikom tijela (značajna povezanost nije pronađena samo sa zadovoljstvom mišićnom masom u mladića). Ipak, te su korelacije u mladića slabe ili niske, dok su u djevojaka uglavnom srednje (niska je povezanost samo sa zadovoljstvom mišićnom masom). U mladića nije pronađena značajna povezanost između ITM-a i varijabli važnosti slike tijela, dok je u djevojaka pronađena tek slaba pozitivna povezanost između ITM-a i važnosti koju djevojke pridaju tjelesnoj težini te važnosti izgleda pojedinih dijelova tijela. Neovisno o spolu sudionika, ITM pokazuje srednju pozitivnu povezanost s korištenjem strategija za smanjenje težine.

U mladića nije pronađena značajna povezanost između mjerenih aspekata zadovoljstva slikom tijela i mjerenih aspekata važnosti slike tijela, osim slabe negativne povezanosti između zadovoljstva tjelesnom težinom i važnosti tjelesne težine. S druge strane, u djevojaka su sve varijable zadovoljstva slikom tijela značajno negativno povezane s važnošću tjelesne težine, oblika tijela i izgleda pojedinih dijelova tijela, no te su korelacije slabe ili niske. Značajna povezanost nije pronađena samo za varijable zadovoljstva slikom tijela i važnosti koju djevojke pridaju veličini i snazi mišića.

Rezultati prikazani u Tablici 4 upućuju na postojanje značajne negativne povezanosti varijabli zadovoljstva slikom tijela i korištenja strategija za smanjenje teži- 


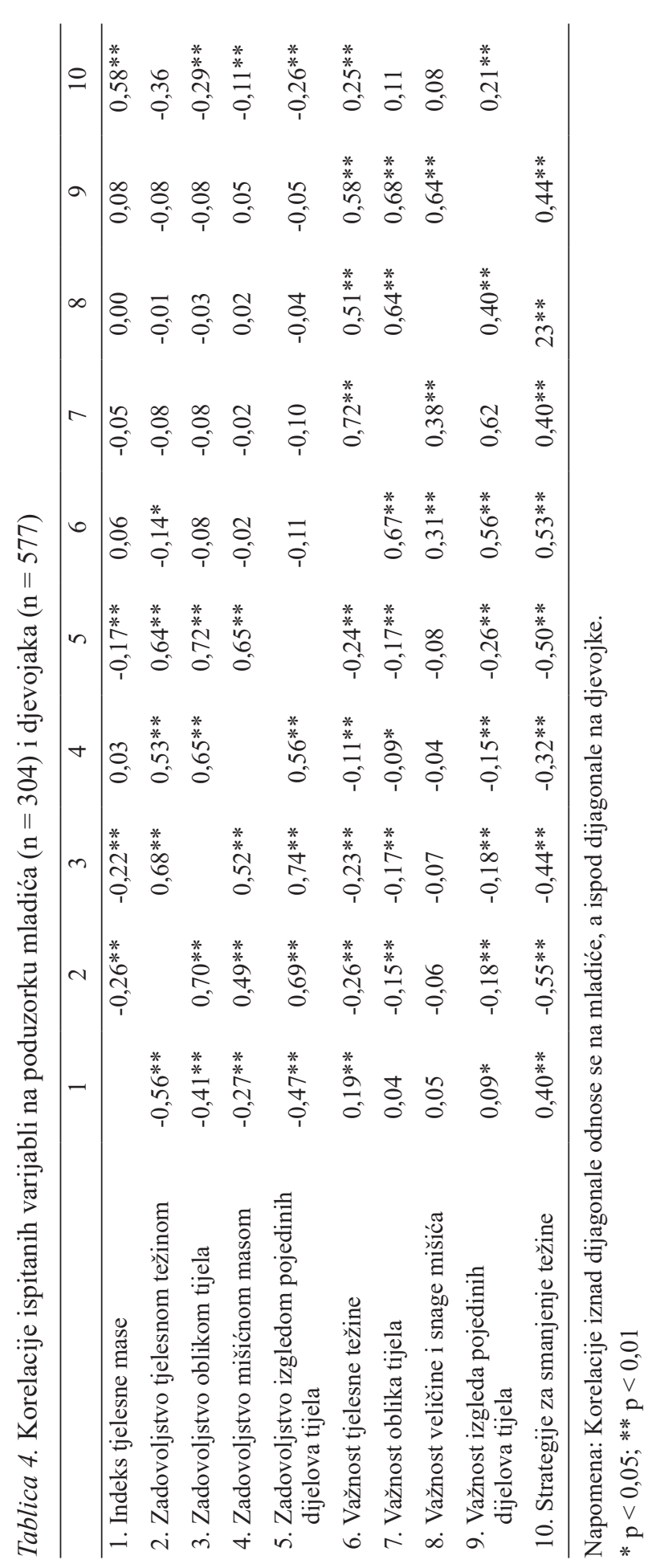


ne. Te su korelacije u mladića slabe ili niske ( $r=-0,11$ do $r=-0,36$ ), a u djevojaka niske ili srednje $(r=-0,32$ do $r=-0,55)$. Također značajne niske ili srednje, no u ovome slučaju pozitivne korelacije $(r=0,23$ do $r=0,53)$ pronađene su u djevojaka između svih varijabli važnosti slike tijela i korištenja strategija za smanjenje težine. U mladića je značajna povezanost (pozitivna i niska) pronađena samo između važnosti tjelesne težine te važnosti izgleda pojedinih dijelova tijela i korištenja strategija za smanjenje težine. Važnost oblika tijela, kao i važnost veličine i snage mišića nisu pokazale značajnu povezanost sa strategijama za smanjenje težine.

Kako bi se ispitao potencijalni moderatorski učinak važnosti koju osoba pridaje slici tijela na odnos između zadovoljstva slikom tijela i korištenja strategija za smanjenje težine, provedene su hijerarhijske regresijske analize s interakcijskim učincima. U svaku je analizu u prvom koraku unesen indeks tjelesne mase (radi kontroliranja utjecaja ove varijable na odnose ostalih varijabli), u drugom koraku jedna od varijabli zadovoljstva slikom tijela, u trećem koraku jedna od varijabli važnosti slike tijela, a u četvrtom koraku interakcije između varijable zadovoljstva slikom tijela iz drugog koraka i varijable važnosti slike tijela iz trećeg koraka. Rezultati ovih hijerarhijskih regresijskih analiza, koje su zbog očekivanih spolnih razlika napravljene zasebno na poduzorku mladića i poduzorku djevojaka, prikazani su u Tablici 5.

Tablica 5. Rezultati hijerarhijskih regresijskih analiza za ispitivanje moderatorskih učinaka važnosti slike tijela na odnos između zadovoljstva slikom tijela i strategija za smanjenje težine kod mladića $(\mathrm{n}=304)$ i djevojaka $(\mathrm{n}=577)$

\begin{tabular}{|c|c|c|c|c|c|c|}
\hline \multirow[b]{2}{*}{ Prediktori / Moderatori } & \multicolumn{3}{|c|}{ Mladići } & \multicolumn{3}{|c|}{ Djevojke } \\
\hline & $\mathrm{R}^{2}$ & $\Delta \mathrm{R}^{2}$ & $\beta$ & $\mathrm{R}^{2}$ & $\Delta \mathrm{R}^{2}$ & $\beta$ \\
\hline 1. korak & 0,33 & & & 0,16 & & \\
\hline Indeks tjelesne mase & & & $0,51 * * *$ & & & $0,10 * *$ \\
\hline 2. korak & 0,38 & $0,05 * * *$ & & 0,31 & $0,16^{* * *}$ & \\
\hline Zadovoljstvo tjelesnom težinom & & & $-0,23 * * *$ & & & $-0,34 * * *$ \\
\hline 3. korak & 0,41 & $0,03 * * *$ & & 0,47 & $0,16^{* * *}$ & \\
\hline Važnost tjelesne težine & & & $0,20 * * *$ & & & $0,43^{* * *}$ \\
\hline 4. korak & 0,42 & $0,01^{*}$ & & 0,48 & $0,01 * * *$ & \\
\hline $\begin{array}{l}\text { Zadovoljstvo težinom } \times \\
\text { Važnost težine }\end{array}$ & & & $-0,10^{*}$ & & & $-0,12 * * *$ \\
\hline 1. korak & 0,33 & & & 0,16 & & \\
\hline Indeks tjelesne mase & & & $0,55 * * *$ & & & $0,27 * * *$ \\
\hline 2. korak & 0,36 & $0,03 * * *$ & & 0,25 & $0,09 * * *$ & \\
\hline Zadovoljstvo oblikom tijela & & & $-0,18 * * *$ & & & $-0,26 * * *$ \\
\hline 3. korak & 0,38 & $0,02 * *$ & & 0,36 & $0,12 * * *$ & \\
\hline Važnost oblika tijela & & & $0,14 * *$ & & & $0,35 * * *$ \\
\hline 4. korak & 0,39 & $0,01^{*}$ & & 0,36 & 0,00 & \\
\hline $\begin{array}{l}\text { Zadovoljstvo oblikom } \times \\
\text { Važnost oblika }\end{array}$ & & & $-0,11^{*}$ & & & $-0,03$ \\
\hline
\end{tabular}




\begin{tabular}{|c|c|c|c|c|c|c|}
\hline \multirow[b]{2}{*}{ Prediktori / Moderatori } & \multicolumn{3}{|c|}{ Mladići } & \multicolumn{3}{|c|}{ Djevojke } \\
\hline & $\mathrm{R}^{2}$ & $\Delta \mathrm{R}^{2}$ & $\beta$ & $\mathrm{R}^{2}$ & $\Delta \mathrm{R}^{2}$ & $\beta$ \\
\hline 1. korak & 0,33 & & & 0,16 & & \\
\hline Indeks tjelesne mase & & & $0,59 * * *$ & & & $0,32 * * *$ \\
\hline 2. korak & 0,35 & $0,02 * *$ & & 0,21 & $0,05 * * *$ & \\
\hline Zadovoljstvo mišićnom masom & & & $-0,11 *$ & & & $-0,23 * * *$ \\
\hline 3. korak & 0,36 & 0,01 & & 0,25 & $0,04 * * *$ & \\
\hline Važnost veličine i snage mišića & & & 0,09 & & & $0,21 * * *$ \\
\hline 4. korak & 0,36 & 0,01 & & 0,25 & 0,00 & \\
\hline $\begin{array}{l}\text { Zadovoljstvo mišićima } \times \\
\text { Važnost mišića }\end{array}$ & & & $-0,08$ & & & 0,01 \\
\hline 1. korak & 0,33 & & & 0,16 & & \\
\hline Indeks tjelesne mase & & & $0,53 * * *$ & & & $0,22 * * *$ \\
\hline 2. korak & 0,36 & $0,03 * * *$ & & 0,28 & $0,13 * * *$ & \\
\hline $\begin{array}{l}\text { Zadovoljstvo izgledom } \\
\text { pojedinih dijelova tijela }\end{array}$ & & & $-0,19 * * *$ & & & $-0,29 * * *$ \\
\hline 3. korak & 0,38 & $0,02 * *$ & & 0,39 & $0,11 * * *$ & \\
\hline $\begin{array}{l}\text { Važnost izgleda pojedinih } \\
\text { dijelova tijela }\end{array}$ & & & $0,19 * * *$ & & & $0,36 * * *$ \\
\hline 4. korak & 0,40 & $0,02 * *$ & & 0,40 & $0,01 *$ & \\
\hline $\begin{array}{l}\text { Zadovoljstvo izgledom } \times \\
\text { Važnost izgleda }\end{array}$ & & & $-0,13 * *$ & & & $-0,07^{*}$ \\
\hline
\end{tabular}

Napomena: Prikazani su beta-koeficijenti iz zadnjeg koraka hijerarhijske regresijske analize. $\mathrm{R}^{2}=$ ukupni doprinos prediktora objašnjenoj varijanci; $\Delta \mathrm{R}^{2}=$ doprinos pojedine grupe prediktora objašnjenoj varijanci.

$* \mathrm{p}<0,05 ; * \mathrm{p}<0,01 ; * * \mathrm{p}<0,001$

Gledajući rezultate četvrtog koraka svake od analiza prikazanih u Tablici 5, vidimo da važnost koju osoba pridaje tjelesnoj težini ima značajan moderatorski učinak na odnos između zadovoljstva tjelesnom težinom i korištenja strategija za smanjenje težine, u mladića i u djevojaka. Neovisno o spolu sudionika, pronađen je i značajan moderatorski učinak važnosti koju osoba pridaje izgledu pojedinih dijelova tijela na odnos između zadovoljstva izgledom pojedinih dijelova tijela $\mathrm{i}$ korištenja strategija za smanjenje težine. Naime, interakcija zadovoljstva tjelesnom težinom i važnosti tjelesne težine značajan je prediktor korištenja strategija za smanjenje težine, isto kao i interakcija zadovoljstva izgledom pojedinih dijelova tijela i važnosti izgleda pojedinih dijelova tijela. Nadalje, važnost koju osoba pridaje obliku tijela ima značajan moderatorski učinak na odnos između zadovoljstva oblikom tijela i korištenja strategija za smanjenje težine, ali samo u mladića. Važnost koju osoba pridaje veličini i snazi mišića nije se pokazala značajnim moderatorom odnosa zadovoljstva veličinom i snagom mišića i korištenja strategija za smanjenje težine niti kod mladića niti kod djevojaka. 


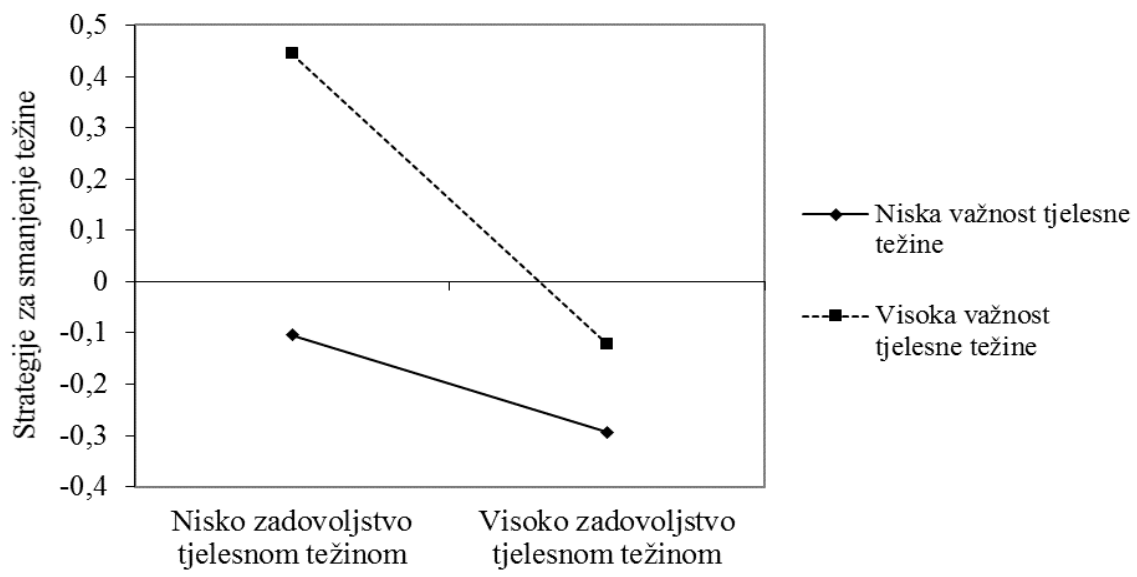

Slika 1. Interakcijski učinak zadovoljstva tjelesnom težinom i važnosti tjelesne težine na korištenje strategija za smanjenje težine u mladića

Na slikama od 1 do 5 prikazani su interakcijski učinci koji su se u hijerarhijskim regresijskim analizama pokazali značajnima. Pri tome su vrijednosti na ordinati, koje se odnose na čestinu korištenja strategija za smanjenje težine, prikazane u zvrijednostima. Na Slici 1 prikazan je interakcijski učinak zadovoljstva tjelesnom težinom i važnosti tjelesne težine na korištenje strategija za smanjenje težine u mladića, a na Slici 2 u djevojaka.

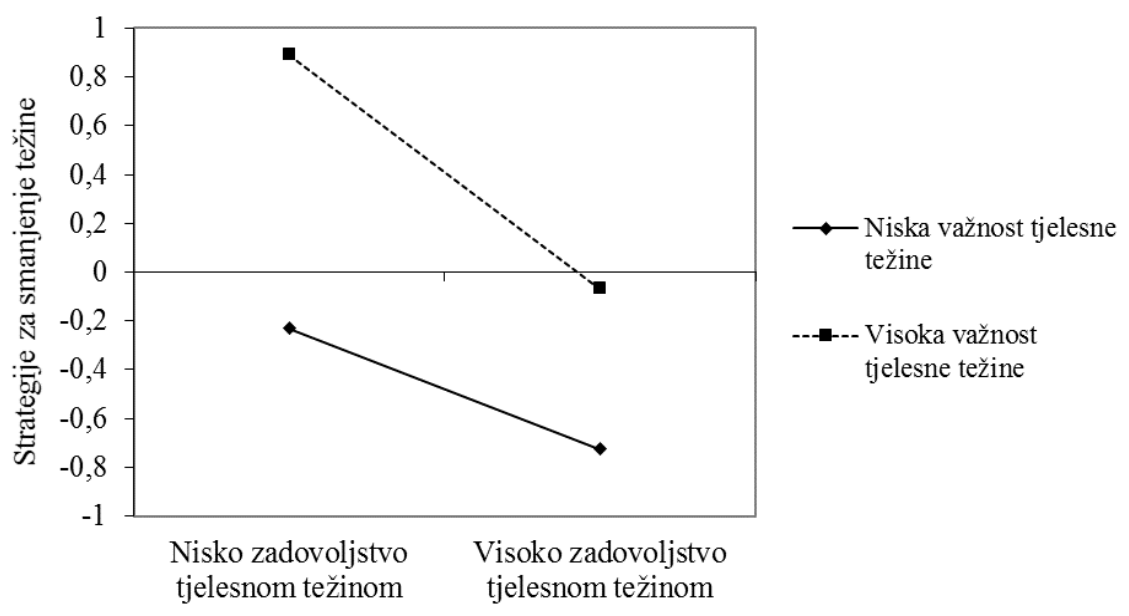

Slika 2. Interakcijski učinak zadovoljstva tjelesnom težinom i važnosti tjelesne težine na korištenje strategija za smanjenje težine u djevojaka 


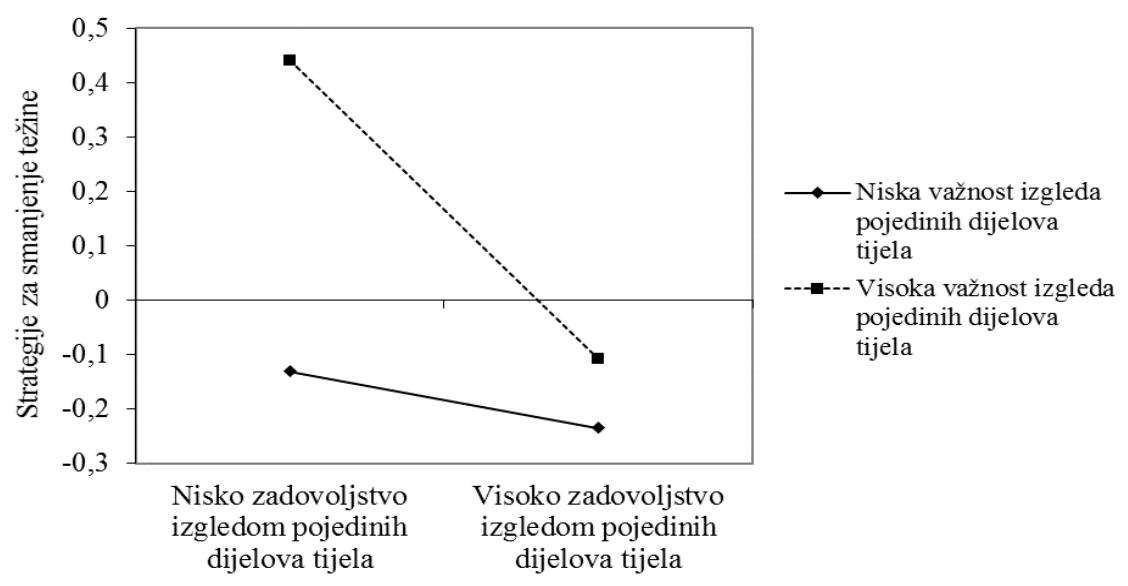

Slika 3. Interakcijski učinak zadovoljstva oblikom tijela i važnosti oblika tijela na korištenje strategija za smanjenje težine u mladića

Iz Slike 1 vidljivo je da mladići koji su nezadovoljni svojom tjelesnom težinom, a pridaju joj visoku važnost, češće koriste strategije za smanjenje težine od mladića koji su također nezadovoljni svojom tjelesnom težinom, ali joj ne pridaju visoku važnost.

Iz Slike 2 vidimo da je kod djevojaka situacija slična kao kod mladića. Djevojke nezadovoljne tjelesnom težinom, a koje joj istovremeno pridaju visoku važnost, češće koriste strategije za smanjenje težine nego djevojke nezadovoljne svojom tjelesnom težinom, ali kojima ona nije osobito važna.

Na Slici 3 prikazan je interakcijski učinak zadovoljstva oblikom tijela i važnosti oblika tijela na korištenje strategija za smanjenje težine u mladića.

Iz Slike 3 vidimo da kod mladića koji pridaju nisku važnost obliku tijela, (ne) zadovoljstvo oblikom tijela nema učinak na korištenje strategija za smanjenje težine. Međutim, pridavanje visoke važnosti obliku tijela u osoba koje su nezadovoljne oblikom svojega tijela, povećava učestalost korištenja strategija za smanjenje težine.

Na Slici 4 prikazan je interakcijski učinak zadovoljstva izgledom pojedinih dijelova tijela i važnosti izgleda pojedinih dijelova tijela na korištenje strategija za smanjenje težine u mladića, a na Slici 5 u djevojaka.

Iz Slike 4 vidimo da je interakcijski učinak zadovoljstva izgledom pojedinih dijelova tijela i važnosti izgleda pojedinih dijelova tijela na korištenje strategija za smanjenje težine u mladića vrlo sličan interakcijskom učinku zadovoljstva oblikom tijela i važnosti oblika tijela. U mladića koji pridaju nisku važnost izgledu pojedinih dijelova tijela, (ne)zadovoljstvo izgledom pojedinih dijelova tijela nema 


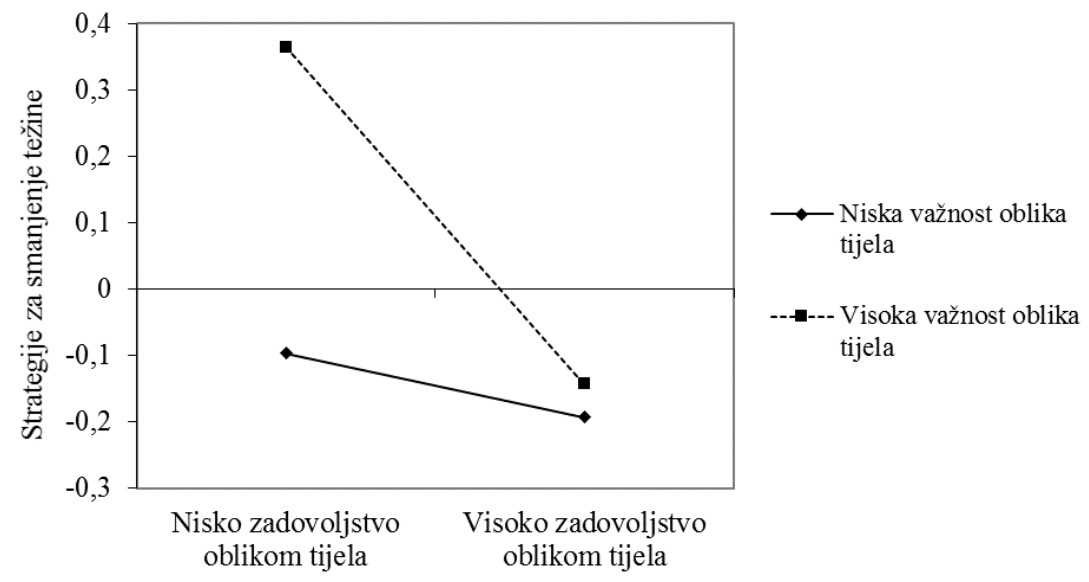

Slika 4. Interakcijski učinak zadovoljstva izgledom pojedinih dijelova tijela i važnosti izgleda pojedinih dijelova tijela na korištenje strategija za smanjenje težine u mladića

učinak na korištenje strategija za smanjenje težine. Međutim, pridavanje visoke važnosti izgledu pojedinih dijelova tijela u osoba koje su nezadovoljne izgledom pojedinih dijelova svojega tijela, povećava učestalost korištenja strategija za smanjenje težine.

Iz Slike 5 vidimo da djevojke nezadovoljne ukupnim izgledom pojedinih dijelova svojega tijela, a koje ujedno pridaju visoku važnost izgledu pojedinih dijelova

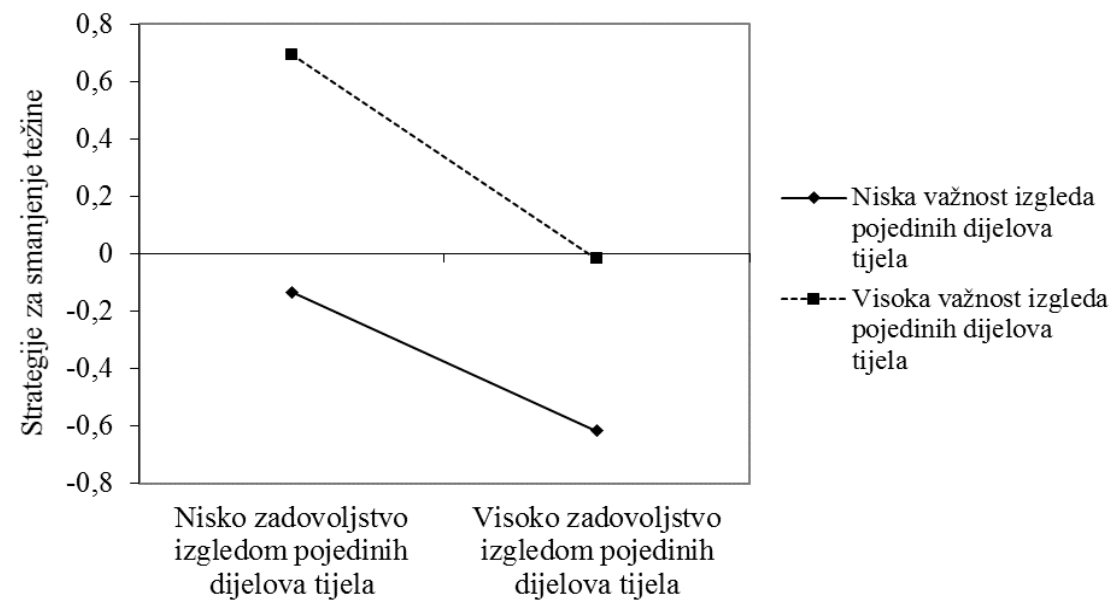

Slika 5. Interakcijski učinak zadovoljstva izgledom pojedinih dijelova tijela i važnosti izgleda pojedinih dijelova tijela na korištenje strategija za smanjenje težine u djevojaka 
tijela, češće koriste strategije za smanjenje težine nego djevojke nezadovoljne izgledom pojedinih dijelova tijela, ali koje tome pridaju nisku važnost.

\section{RASPRAVA}

Jedan od ciljeva ovoga istraživanja bio je ispitati razlike između mladića i djevojaka u važnosti koju pridaju tjelesnom izgledu, zadovoljstvu slikom tijela te učestalosti korištenja strategija za smanjenje težine. Rezultati su pokazali da djevojke pridaju veću važnost obliku tijela, tjelesnoj težini te izgledu pojedinih dijelova tijela, a mladići svojoj mišićavosti. Iako dosadašnja istraživanja koja su uspoređivala mladiće i djevojke adolescentne dobi s obzirom na važnost slike tijela nisu dala ujednačene rezultate (McCabe i Ricciardelli, 2001; McCabe i Ricciardelli, 2005; McCabe i sur., 2010), rezultati ovoga istraživanja u skladu su s postavljenim hipotezama. Naime, upravo ovakve spolne razlike u važnosti pojedinih aspekata tjelesnog izgleda mogu se očekivati kao odraz društvenih ideala ljepote i sociokulturalnih pritiska k postizanju takvih ideala. Kao što je već spomenuto u uvodu, standardi ljepote za žene bitno se razlikuju od onih za muškarce. Društveni ideal ženske ljepote naglašava poželjnost vitkosti i ekstremne mršavosti, a ideal muške privlačnosti mišićavo, "trokutasto" tijelo dobro razvijenog torza (Tiggemann, 2011). Rezultati istraživanja pokazuju da mediji, roditelji i vršnjaci porukama koje odašilju utječu na internalizaciju ideala ljepote te da su mladići i djevojke koji su izloženi većem sociokulturalnom pritisku k postizanju idealnog izgleda skloniji pridavati veću važnost slici tijela (McCabe i Ricciardelli, 2003; McCabe i sur., 2010; Ricciardelli i McCabe, 2003). Sociokulturalni pritisak k postizanju tjelesnog ideala veći je u žena nego u muškaraca (Wertheim, Paxton i Blaney, 2004). Osim prikazivanjem modela idealne tjelesne figure, mediji prikazivanjem ljepote kao esencijalne crte ženske kompetencije i postignuća (Striegel-Moore, 1995) stavljaju dodanu težinu na važnost tjelesnog izgleda u žena. Isto tako, prezentirajući različite načine postizanja "idealnoga" izgleda, još više naglašavaju važnost izgradnje vitkog, odnosno mišićavog tijela (Jones, Bain i King, 2008). Zbog svega navedenog, ne iznenađuje nalaz da djevojke pridaju veću važnost svom tjelesnom izgledu nego mladići te da veću važnost pridaju upravo tjelesnoj težini i obliku tijela, dok mladići smatraju važnijima veličinu i snagu mišića.

Rezultati ovoga istraživanja pokazali su da su mladići općenito zadovoljniji svojim tjelesnim izgledom nego djevojke. U odnosu na djevojke, zadovoljniji su tjelesnom težinom, oblikom tijela, te izgledom pojedinih dijelova svojega tijela, što je u skladu s rezultatima većine dosadašnjih istraživanja (primjerice, Barker i Galambos, 2003; Pokrajac-Bulian i sur., 2007; Ricciardelli i McCabe, 2001). Diskrepanca koju percipiramo između vlastitoga i željenoga, idealnoga izgleda predstavlja srž nezadovoljstva tijelom (Gardner i sur., 1999). Budući da je u zapadnjačkom društvu danas prihvaćen ideal ženske ljepote koji malo koja djevojka 
može dostići, a istovremeno je društveni ideal muške ljepote manje ekstreman (Tiggemann, 2011), može se očekivati da će djevojke češće nego mladići uočavati diskrepancu između trenutačnog i željenoga izgleda te biti nezadovoljnije. Osim toga, društvena okolina pruža pojedincu povratnu informaciju o uklapanju u društvene norme i ideale (Halpern, King, Oslak i Udry, 2005) pa su i s te strane djevojke u nepovoljnijem položaju. Osobe koje svojim izgledom odstupaju od standarda ljepote mogu biti izložene negativnim komentarima, vršnjačkom zadirkivanju, savjetima o metodama za promjenu tjelesnog izgleda i slično, što će također doprinijeti razvoju nezadovoljstva.

Ovim istraživanjem dobiven je nalaz da djevojke značajno češće nego mladići koriste strategije za smanjenje težine. Takve rezultate ističu i drugi autori. Primjerice, Ambrosi-Randić (2001) navodi da se 31\% učenica i 18,4\% učenika osnovnih i srednjih škola u Hrvatskoj može smatrati umjerenim "dijetalcima", dok 9,3\% učenica i 4,1\% učenika provodi ekstremnu dijetu. Ovakvi rezultati nisu iznenađujući. Spolne razlike u korištenju postupaka za smanjenje težine odražavaju razlike u društvenim idealima muške i ženske ljepote (mišićavost, spram mršavosti) i sociokulturalnom pritisku k postizanju idealnog tjelesnog izgleda, kao i razlike u važnosti koju mladići, odnosno djevojke pridaju pojedinim aspektima izgleda, što su pokazali i rezultati ovoga istraživanja. Dok za djevojke najveću važnost imaju njihova tjelesna težina i oblik tijela, mladići najvažnijom komponentom svojega izgleda smatraju mišićavost. Djevojke su, čak i neovisno o indeksu tjelesne mase, sklone korištenju nezdravih metoda za smanjenje tjelesne težine, dok kod mladića to nije slučaj (Neumark-Sztainer, Story, Falkner, Beuhring i Resnick, 1999). Ipak, istraživanja pokazuju da je u oba spola stupanj uhranjenosti povezan s nezadovoljstvom tijelom. U skladu s današnjim društvenim idealima ženske, odnosno muške ljepote, u djevojaka je odnos ITM-a i nezadovoljstva linearan (veći ITM, veće nezadovoljstvo), a u mladića zakrivljen (Smolak, 2004), na način da su u mladića prekomjerna tjelesna težina, ali i pothranjenost prediktori nezadovoljstva (Presnell, Bearman i Stice, 2004). Stoga nezadovoljstvo slikom tijela u žena uvijek ide u smjeru gubitka tjelesne težine, dok u muškaraca ide i u smjeru gubitka težine, ali i u smjeru dobivanja na tjelesnoj težini, prvenstveno mišićne mase (Furnham i Calnan, 1998). Prekomjerno teški mladići skloni su korištenju nezdravih metoda za smanjenje težine, a pothranjeni onih za povećanje težine (Neumark-Sztainer i sur., 1999), kao što su uzimanje steroida, velikih količina hrane i pretjerana tjelovježba (Lawrie, Sullivan, Davies i Hill, 2007; McCabe i Ricciardelli, 2004).

Autori nekih od istraživanja koja se bave ispitivanjem zadovoljstva slikom tijela i njenim utjecajem na druge aspekte života, naglašavaju složenost odnosa među navedenim varijablama. Smatraju da je u modele potrebno uključiti i varijablu važnosti slike tijela, jer će upravo ona odrediti kakav će utjecaj nezadovoljstvo slikom tijela imati na funkcioniranje osobe (primjerice, Ricciardelli i McCabe, 2001; Rieder i Ruderman, 2001). Rezultati ovoga istraživanja potvrdila su takva shvaćanja. Mladići i djevojke koji su nezadovoljni svojom tjelesnom težinom, a ujedno joj 
pridaju visoku važnost, češće koriste strategije za smanjenje težine nego oni koji su također nezadovoljni svojom tjelesnom težinom, ali joj ne pridaju visoku važnost. Isti je obrazac prisutan u međuodnosu važnosti izgleda pojedinih dijelova tijela, nezadovoljstva izgledom pojedinih dijelova tijela i korištenja strategija za smanjenje težine. Možemo pretpostaviti da će oni koji su nezadovoljni tjelesnom težinom ili izgledom pojedinih dijelova tijela, a ujedno te karakteristike smatraju važnim aspektom svojega života, biti motiviraniji koristiti određene metode za smanjenje tjelesne težine (promjene navika hranjenja, pojačanu tjelovježbu te korištenje pripravaka za mršavljenje) kako bi se približili idealu izgleda i postali zadovoljniji sobom. Rieder i Ruderman (2001) naglašavaju da će osobe koje su nezadovoljne vlastitom težinom, ali kojima je slika tijela tek marginalno važna, biti manje motivirane koristiti metode za kontrolu težine. Samo nezadovoljstvo tjelesnom težinom ne dovodi nužno do uporabe postupaka za smanjenje težine.

Pomalo su neobični rezultati ovog istraživanja koji pokazuju da je moderatorski učinak važnosti oblika tijela na odnos između zadovoljstva oblikom tijela i korištenja strategija za smanjenje težine značajan u mladića, ali ne i u djevojaka. Stoga su potrebna daljnja istraživanja kojima bi se pokušao razjasniti ovaj odnos, ispitujući koje su još varijable potencijalno uključene u njega.

U ovome istraživanju, jedino se interakcijski učinak zadovoljstva mišićima i važnosti mišića na korištenje strategija za smanjenje težine nije pokazao značajnim niti kod mladića niti kod djevojaka, što se i očekivalo s obzirom na vrstu ispitivanih strategija za promjenu tjelesnog izgleda. Vjerojatno bi odnos među varijablama bio drukčiji da smo u analizu umjesto učestalosti korištenja strategija za smanjenje težine, uključili varijablu učestalosti korištenja strategija za povećanje mišićavosti. Tada bismo možda mogli očekivati moderatorsku ulogu važnosti mišićavosti.

Zaključno, ovo je istraživanje pokazalo da su djevojke nezadovoljnije slikom tijela, pridaju joj veću važnost te češće koriste strategije za smanjenje težine nego mladići. Osim toga, istraživanje nam pruža dodatne spoznaje o ulozi važnosti slike tijela $u$ adolescenata. Posebno je značajan nalaz o važnosti slike tijela kao moderatoru odnosa između nezadovoljstva slikom tijela i korištenja strategija za smanjenje težine. Rezultati ovoga istraživanja mogu koristiti kao smjernice za osmišljavanje preventivnih programa usmjerenih na nezadovoljstvo slikom tijela i njegove posljedice. Preventivnim programima i tretmanima trebalo bi pokušati usmjeriti adolescente na pridavanje veće važnosti nekim svojim poželjnim vještinama i sposobnostima, a koje nisu vezane uz tjelesni izgled.

Ovo istraživanje ima i određenih nedostataka. Oni se prvenstveno odnose na način prikupljanja podataka. Aspekti slike tijela, kao i učestalost korištenja strategija za smanjenje težine procjenjivani su mjerama samoprocjene, a podaci o tjelesnoj težini i visini dobiveni su samoiskazom sudionika. Osim toga, neki od aspekata slike tijela mjereni su samo jednom česticom. U budućim bi istraživanjima trebalo, kad god je to moguće, primjenjivati objektivnije metode za dolaženje do podataka. Također, bilo bi poželjno detaljnije ispitati pojedine varijable: primjerice, obu- 
hvatiti još neke postupke koje ljudi koriste s ciljem smanjenja tjelesne težine (npr. post, povraćanje) te ispitati važnost još nekih karakteristika tjelesnoga izgleda, kao i zadovoljstvo istima. Konačno, korištenje longitudinalnih nacrta u budućim istraživanjima osiguralo bi dobivanje informacija o prirodi odnosa među ispitivanim varijablama tijekom vremena.

\section{LITERATURA}

Ambrosi-Randić, N. (2001). Učestalost i korelati provođenja dijete tijekom adolescencije. Društvena istraživanja, 53, 415-430. Preuzeto sa http://hrcak.srce.hr/20015

Barker, E. T. i Galambos, N. L. (2003). Body dissatisfaction of adolescent girls and boys: Risk and resource factors. The Journal of Early Adolescence, 23, 141-165. DOI: $10.1177 / 0272431603023002002$

Beck, J. S. (2011). Osnove kognitivne terapije. Jastrebarsko: Naklada Slap.

Bralić, I. i Kovačić, V. (2005). Social and behavioural determinants of body mass index among adolescent females in Croatia. Public Health, 119, 189-191. DOI: 10.1016/j. puhe.2004.04.005

Calderon, L. L., Yu, C. K. i Jambazian, P. (2004). Dieting practices in high school students. Journal of the American Dietetic Association, 104, 1369-1374. DOI: 10.1016/j. jada.2004.06.017

Cooper, P. J. i Fairburn, C. G. (1993). Confusion over the core psychopathology of bulimia nervosa. International Journal of Eating Disorders, 13, 385-389. DOI: 10.1002/1098-108X(199305)13:4<385::AID-EAT2260130406>3.0.CO;2-W

Crow, S., Eisenberg, M. E., Story, M. i Neumark-Sztainer, D. (2006). Psychosocial and behavioral correlates of dieting among overweight and non-overweight adolescents. Journal of Adolescent Health, 38, 569-574. DOI: 10.1016/j.jadohealth.2005.05.019

French, S. A. i Jeffery, R. W. (1994). Consequences of dieting to lose weight: Effects on physical and mental health. Health Psychology, 13, 195-212. DOI: 10.1037\%2F02786133.13.3.195

Furnham, A. i Calnan, A. (1998). Eating disturbance, self-esteem, reasons for exercising and body weight dissatisfaction in adolescent males. European Eating Disorders Review, 6, 58-72. DOI: 10.1002/(SICI)1099-0968(199803)6:1<58::AID-ERV184>3.0.CO;2-V

Gardner, R. M., Friedman, B. N. i Jackson, N. A. (1999). Body Size Estimations, Body Dissatisfaction, and Ideal Size Preferences in Children Six Through Thirteen. Journal of Youth and Adolescence, 28, 603-618. DOI: 10.1023/A:1021610811306

Goldschmidt, A. B., Aspen, V. P., Sinton, M. M., Tanofsky-Kraff, M. i Wilfley, D. E. (2008). Disordered eating attitudes and behaviors in overweight youth. Obesity, 16, 257-264. DOI: $10.1038 /$ oby.2007.48

Gutin, B. (2011). Diet vs exercise for the prevention of pediatric obesity: The role of exercise. International Journal of Obesity, 35, 29-32. DOI:10.1038/ijo.2010.140

Halpern, C. T., King, R. B., Oslak, S. G. i Udry, J. R. (2005). Body mass index, dieting, romance, and sexual activity in adolescent girls: Relationships over time. Journal of Research on Adolescence, 15, 535-559. DOI: 10.1111/j.1532-7795.2005.00110.x 
Jones, D. C., Bain, N. i King, S. (2008). Weight and muscularity concerns as longitudinal predictors of body image among early adolescent boys: A test of the dual pathway model. Body Image, 5, 195-204. DOI: 10.1016/j.bodyim.2007.12.001

Jureša, V., Musil, V. i Kujundžić Tiljak, M. (2010). Hrvatske referentne vrijednosti tjelesne mase, tjelesne visine i indeksa tjelesne mase kod dječaka i djevojčica u dobi od 6,5 do 18,5 godina. Preuzeto sa http://www.mef.unizg.hr/druga.php?grupa=020332050100.

Knez, R. (2003). Poremećaj hranjenja uzrokovan prehrambenim navikama adolescenata. (Neobjavljen magistarski rad). Medicinski fakultet, Sveučilište u Rijeci, Rijeka.

Kukić, M. (2013). Pretilost adolescenata - rizični i zaštitni čimbenici. (Neobjavljena doktorska disertacija). Filozofski fakultet, Sveučilište u Zagrebu, Zagreb.

Lawrie, Z., Sullivan, E. A., Davies, P. S. W. i Hill, R. J. (2007). Body change strategies in children: Relationship to age and gender. Eating Behaviors, 8, 357-363. DOI: 10.1016/j. eatbeh.2006.11.011

Levine, M. P. i Smolak, L. (2002). Body image development in adolescence. U: T. F. Cash i T. Pruzinsky (Ur.), Body Image: A Handbook of Theory, Research and Clinical Practice (str. 74-83). New York: The Guilford Press.

McCabe, M. P. i Ricciardelli, L. A. (2005). A prospective study of pressures from parents, peers, and the media on extreme weight change behaviors among adolescent boys and girls. Behaviour Research and Therapy, 43, 653-668. DOI: 10.1016/j.brat.2004.05.004

McCabe, M. P. i Ricciardelli, L. A. (2004). A longitudinal study of pubertal timing and extreme body change behaviors among adolescent boys and girls. Adolescence, 39, 145-166. Preuzeto sa http://psycnet.apa.org/record/2004-15075-010

McCabe, M. P. i Ricciardelli, L. A. (2003). Sociocultural influences on body image and body changes among adolescent boys and girls. The Journal of Social Psychology, 143, 5-26. DOI: $10.1080 / 00224540309598428$

McCabe, M. P. i Ricciardelli, L. A. (2001). Parent, peer and media influences on body image and strategies to both increase and decrease body size among adolescent boys and girls. Adolescence, 36, 225-240. Preuzeto sa https:/www.ncbi.nlm.nih.gov/ pubmed/11572302

McCabe, M. P., Ricciardelli, L. A. i Holt, K. (2010). Are there different sociocultural influences on body image and body change strategies for overweight adolescent boys and girls? Eating Behaviors, 11, 156-163. DOI: 10.1016/j.eatbeh.2010.01.005

McCabe, M. P., Ricciardelli, L. A. i Holt, K. (2005). A longitudinal study to explain strategies to change weight and muscles among normal weight and overweight children. Appetite, 45, 225-234. DOI: 10.1016/j.appet.2005.07.009

Muris, P., Meesters, C., van de Blom, W. i Mayer, B. (2005). Biological, psychological, and sociocultural correlates of body change strategies and eating problems in adolescent boys and girls. Eating Behaviors, 6, 11-22. DOI: 10.1016/j.eatbeh.2004.03.002

Neumark-Sztainer, D. M., Story, M., Falkner, N. H., Beuhring, T. i Resnick, M. D. (1999). Sociodemographic and personal characteristics of adolescents engaged in weight loss and weight/muscle gain behaviors: Who is doing what? Preventive Medicine, 28, 40-50. Preuzeto sa http://www.uptodate.com/contents/adolescent-eating-habits/abstract/155

Peternel, L. i Sujoldžić, A. (2009). Adolescents eating behavior, body image and psycho- 
logical well-being. Collegium Antropologicum, 33, 205-212. Preuzeto sa http://hrcak. srce.hr/39560

Pokrajac-Bulian, A., Mohorić, T. i Đurović, D. (2007). Odstupajuće navike hranjenja, nezadovoljstvo tijelom i učestalost provođenja dijete kod hrvatskih srednjoškolaca. Psihologijske teme, 16, 27-46. Preuzeto sa http://hrcak.srce.hr/20507

Presnell, K., Bearman, S. K. i Stice, E. (2004). Risk factors for body dissatisfaction in adolescent boys and girls: a prospective study. International Journal of Eating Disorders, 36, 389-401. DOI: 10.1002/eat.20045

Ricciardelli, L. A. i McCabe, M. P. (2003). Sociocultural and individual influences on muscle gain and weight loss strategies among adolescent boys and girls. Psychology in the Schools, 40, 209-224. DOI: 10.1002/pits.10075

Ricciardelli, L. A. i McCabe, M. P. (2001). Self-esteem and negative affect as moderators of sociocultural influences on body dissatisfaction, strategies to decrease weight, and strategies to increase muscles among adolescent girls and boys. Sex Roles, 44, 189-207. DOI: $10.1023 / \mathrm{A}: 1010955120359$

Ricciardelli, L. A. i McCabe, M. P. (2000). Psychometric evaluation of the Body Image and Body Change Inventory: An assessment instrument for adolescent boys and girls. Neobjavljeni rad.

Ricciardelli, L. A., McCabe, M. P., Holt, K. E. i Finemore, J. (2003). A biopsychosocial model for understanding body image and body change strategies among children. Applied Developmental Psychology, 24, 475-495. DOI: 10.1016/S0193-3973(03)00070-4

Rieder, S. i Ruderman, A. (2001). Cognitive factors associated with binge and purge eating behaviors: The interaction of body dissatisfaction and body image importance. Cognitive Therapy and Research, 25, 801-812. DOI: 10.1023/A:1012979625364

Rosen, J. C. (1992). Body-image disorder: Definition, development, and contribution to eating disorders. U: J. H. Crowther, D. L. Tennenbaum, S. E. Hobfoll i M. A. Parris Stephens (Ur.), The Etiology of Bulimia Nervosa: The Individual and Familial Context (str. 157-177). Washington: Hemisphere Publishing Corporation.

Smolak, L. (2004). Body image in children and adolescents: Where do we go from here? Body Image, 1, 15-28. DOI: 10.1016/S1740-1445(03)00008-1

SPSS Inc. (2006). SPSS for Windows, Version 15.0. Chicago: SPSS Inc.

Striegel-Moore, R. H. (1995). A feminist perspective on the etiology of eating disorders. U: K. Brownell i C. G. Fairburn (Ur.), Eating Disorders and Obesity (str. 224-229). New York: Guilford Press.

Sujoldžić, A. i De Lucia, A. (2007). A cross-cultural study of adolescents - BMI, body image and psychological well-being. Collegium Antropologicum, 31, 123-130. Preuzeto sa http://hrcak.srce.hr/27326

Škreblin, L. (2003). Antropološko istraživanje prehrambenih navika i biometrijska procjena prehrambenog statusa adolescenata. (Neobjavljen magistarski rad). Prirodoslovno-matematički fakultet, Sveučilište u Zagrebu, Zagreb.

Thompson, J. K., Heinberg, L. J., Altabe, M., Tantleff-Dunn, S. (1999). Exacting Beauty: Theory, Assessment, and Treatment of Body Image Disturbance. Washington, DC: American Psychological Association.

Thompson, J. K. i Stice, E. (2001). Thin-ideal internalization: Mounting evidence for a 
new risk factor for body-image disturbance and eating pathology. Current Directions in Psychological Science, 10, 181-183. DOI: 10.1111/1467-8721.00144

Tiggemann, M. (2011). Sociocultural perspectives on human appearance and body image. U: T. F. Cash i L. Smolak (Ur.), Body Image: A Handbook of Science, Practice, and Prevention (str. 12-19). New York: The Guilford Press.

Wertheim, E. H., Paxton, S. J. i Blaney, S. (2004). Risk factors for the development of body image disturbances. U: J. K. Thompson (Ur.), Handbook of Eating Disorders and Obesity (str. 463-494). New York: John Wiley and Sons.

\title{
BODY IMAGE IMPORTANCE AS A MODERATOR OF THE EFFECT OF BODY IMAGE DISSATISFACTION ON THE USE OF WEIGHT REDUCTION STRATEGIES
}

\begin{abstract}
The aim of this research was to examine gender differences in body image and the use of weight reduction strategies, and to examine a possible moderating effect of body image importance on the relationship between body image dissatisfaction and the use of weight reduction strategies in adolescents.

A total of 913 high school students $(65.7 \%$ girls; mean age $16.2 \pm 1.18$ years) participated in the study. They completed the Body Image and Body Change Inventory.

The results showed that, in general, girls are more dissatisfied with their body image, estimate their body image to be more important, and they use weight reduction strategies more frequently than do boys. The results of regression analyses showed that body image importance moderates the relationship between body image dissatisfaction and the use of weight reduction strategies. Boys and girls who are dissatisfied with their body weight and who, at the same time, estimate their body weight as important to them, use weight-reduction strategies more often than boys and girls who are dissatisfied with their body weight, but who do not estimate their body weight to be particularly important to them. The same pattern is present in the relationship among the importance of the appearance of individual body parts, dissatisfaction with the appearance of individual body parts and the use of weight reduction strategies.

This research provided an additional insight into the role of body image importance in adolescents. The results of this study could be used as guidelines for the design of prevention programs focused on body image dissatisfaction and the consequences it brings.
\end{abstract}

Key words: body image dissatisfaction, body image importance, strategies to lose weight, adolescence 
